AMERICAN JOURNAL BIOTECHNOLOGY AND MOLECULAR SCIENCES

ISSN Print: 2159-3698, ISSN Online: 2159-3701, doi:10.5251/ajbms.2011.1.2.45.50

(C) 2011, ScienceHu $\beta$, http://www.scihub.org/AJBMS

\title{
Effect of fruit fermentation on the germination and growth of Irvingia wombolu (Vermoesen) seedlings
}

\author{
Dickens Dolor \\ Department of Forestry and Wildlife, Delta State University Asaba, Campus, Nigeria. \\ Email: dickensdolor@ yahoo.co.uk.
}

\begin{abstract}
This study evaluated the effect of seed fermentation processing on the germination and seedling performance of Irvingia wombolu. The experiment was conducted at the Teaching and Research Farm of the Delta State University, Asaba Campus, Nigeria. The results revealed a highly significant $(P=0.001)$ effect of seed fermentation on germination percentage, plant height, number of leaves, leaf area and dry weight. Germination percentage ranged from $0 \%$ to $50 \%$ in 2- 4 weeks to 0 week fermentation. Fruit fermentation is not recommended and Irvingia wombolu seeds should mechanical depulped and sown immediately they are collected.
\end{abstract}

Keywords: Irvingia wombolu, fermentation, germination, seedling emergence.

\section{INTRODUCTION}

Irvingia wombolu and I. wombulu commonly called bush mango or dika nut are an important high-value indigenous multi-purpose tree species found in West and Central Africa (Harris, 1996; Lowe et al., 2000; Atangana et al., 2002). These species produce the edible nuts widely marketed within and outside the region (Leakey, 1999; Ladipo, 2000) and form an important diet providing carbohydrates, oils and proteins to enhance health and nutrition (Fajimi et al., 2007). The fruit of Irvingia gabonensis has a sweet mesocarp and it is eaten fresh while that of Irvingia wombolu is sour and is not consumed locally (Okafor, 1975; Leakey, 1999; Fajimi et al., 2007).

Most of the trees that are at present of great importance to farmers have been growing in the wild, as they have not been domesticated. Constraints to domestication of the species include the long gestation period of seed sown trees (Moss, 1995; Ladipo et al., 1996), poor germination capacity ( Nya et al., 2000) variability of fruits and kernel characteristics, variability in tree size ( Ladipo et al.,1996, Schreckenberg et al., 2001) and limited knowledge base ( Tchoundjeu et al., 2002). Although bush mango is recently being domesticated, less than 10 percent of the total annual harvest of fruits or kernel is harvested from planted trees while the rest are collected from the natural forests (Ladipo, 2000). Seed is the common propagation material for most tropical tree species (Bowes, 1999). Propagation from seed is inexpensive and usually effective, and is therefore a viable method for their ex-situ conservation (Abirami et al., 2010). Obviously, an understanding of seed physiology could expectedly contribute to the effort of seed-based in-situ conservation as well as ex-situ cultivation (Sharma and Sharma, 2006). The proper handling of seed through the processes of ripening or maturation, collecting, processing, storage (if needed), dormancy, stratification and germination is required for success in producing a new seedling. Often, seed ripening and collection does not correspond with the time of seedling production, while some species do not produce seeds all year round. Seed storage is therefore vital to secure the supply of good quality and quantity seeds for planting programme (Onyekwelu and Fayose, 2007; Siddique and Wright, 2003).

According to Willan, (1985) if seeds are not extracted in the field, great care must be taken of the fruits both in the forest and during transport. Bulk quantities of fruits in high temperature and humidity are very susceptible to deterioration through the action of moulds and other fungi and through overheating due to a high rate of respiration. The majority of seeds in the humid tropics are recalcitrant, include a number of large seeds that cannot withstand appreciable drying without injury and as a result there is high rates of seed spoilage. Since recalcitrant seeds (and their fruits) respire actively, they require good ventilation. If large quantities are closely packed, suffocation, physiological breakdown, fungal growth, and overheating will occur resulting in rapid death of the seeds. The seeds of species with fleshy fruits are enclosed with soft pulp that can decay and cause injury (Schopmeyers, 1974). The fleshy tissues or pulp should be removed to prevent damage to the 
embryo from spontaneous heating or an imbibiting substance (MacDonald, 1986). For extraction of small seed lots, fruits may be cut open and seeds scooped out or allowed to rot and treaded in tubs or rubbed through screens (Steiner and Letizia, 1986: Hartmann et al., 2007). Commercial processing or seed extraction of plants with fleshy fruits such as berries, pomes and drupes may involve maceration, fermentation and chemical treatment (Desai et al., 1987). Macerated fruits placed in barrels or vats are allowed to ferment for up to 4 days at about $21^{\circ}$ Celsius. Extraction by fermentation for some seeds such as tomatoes may help control bacterial canker (Liptay, 1989). There are several reported methods for the obtaining the kernels from Irvingia fruits. Traditionally the fruits are piled up in heaps and left to ferment before the seeds are extracted (Ejiofor 1994). Alternatively, the fruits can be split open with a cutlass to reveal the hard seed inside (Ladipo et al., 1996; Ayuk et al. 1999).The fresh fruits of I. gabonensis have a shelf life of less than 2 days if picked when ripe and not more than 10 days if harvested at the mature green stage due to high respiration rate, moisture loss and microbial attack (Joseph and Aworh 1991, 1992).

Presently, farmers maintain mature bush mango trees that are already grown on their land and will also transplant seedlings onto their farms (Ayuk et al., 1999). New seedlings are also raised from selected seeds from trees that are known to produce high yields of good fruits or from seeds procured from the market. However, the most common source of new stock for cultivation is from the forest (Tchoundjeu et al., 1997, cited by Ainge and Brown, 2001). According to Nya et al. (2006), one major difficulty in Irvingia wombolu domestication is related to its poor seed germination potential which is less than $50 \%$ germination capacity when freshly collected and sown and this can be increased considerably by pre-germination treatment. Therefore for nursery establishment of a particular species for the production of maximum number of quality seeding with minimum cost, time and labour, appropriate seed pre- treatments are required (Hossain et al., 2005). While pre-germination trials aimed at enhancing the germination of many tropical species have been reported (Awodoyin et al., 2001; Aduradola et al., 2005; Nya et al., 2006), no studies on the effect of seed fermentation processing on the seedling emergence and growth of Irvingia wombolu have been carried out. The objective of the study is to evaluate the germination and seedling performance of $I$. wombolu as influenced by duration of fermentation during seed processing.

\section{MATERIALS AND METHODS}

The experiment was carried out at the Delta State University, Asaba Campus (06 $14^{\prime} \mathrm{N}$ and $\left.06^{\circ} 49^{\prime} \mathrm{E}\right)$ in Oshimili South local Government Area of Delta State, Nigeria. Asaba lies in the tropical rainforest zone with annual rainfall range of $1500 \mathrm{~mm}$ to $1849.3 \mathrm{~mm}$. Mean temperature are $23.3^{\circ} \mathrm{Celsius}$ with a maximum of $37.3^{\circ} \mathrm{Celsius}$. Mean monthly soil temperature at $100 \mathrm{~cm}$ depth and sunshine is $28.3^{\circ} \mathrm{Celsius}$ and 4.8 hours respectively (Asaba Meteorological Centre 2003)

Four hundred fruits of $I$. wombolu were procured from fruit collectors at Ossissa, Delta State. The seeds were depulped and for natural fermentation, the slurry containing seeds were placed in plastic containers and kept for $0,1,2,3$ and 4 weeks respectively. The seeds were cleaned at the end of the period allotted before sowing. The planting media consisted of topsoil filled into $45 \mathrm{~cm} \times 45 \mathrm{~cm} \times 30 \mathrm{~cm}$ germination boxes. The seeds were sown in the media and arranged in a completely randomized design. Each treatment was replicated 4 times with daily watering to field capacity. The parameters assessed weekly included germination percentage, plant height, leaf number, and leaf area, seedling biomass production was assessed 8 weeks after sowing.

The seed germination criterion was visible protrusion on the soil surface of at least $0.5 \mathrm{~cm}$ of the cotyledon and hypocotyls of the seedlings. At the end of the experiment, five seedlings from each replicate were randomly selected and uprooted. The uprooted seedlings were then separated into leaf, stem and root components and dried in an electric even at 70 degree Celsius until a constant weight was obtained for biomass assessment.

Data collected were subjected to analysis of variance (ANOVA) and significant means were separated by Fisher's Least Significant Difference (LSD) at 5\% level of probability, using Genstat 3 Discovery edition (Genstat 2007). Prior to ANOVA, all percentage data were arcsine transformed, plant height, leaf area, and dry weight data were log transformed while the number of leaves was square root transformed, (Gomez and Gomez 1984).

\section{RESULTS}

Effect of seed fermentation on germination percentage is highly significant $(P<0.001)$ with 0 
week displaying higher percentage than 1 week, which is in turn higher than the rest treatments when rooting commenced in Weeks 3 , (Table 1). This trend was maintained throughout the period of the trail such that at the final assessment at Week 8, germination was $41.5 \%$ in 0 fermentation and $49.9 \%$ in 1 week fermentation. The viability of the seeds were apparently lost when the seeds were fermented beyond 1 week as no seeds germinated in the 2 week to 4 week seed fermented treatments.

Similarly, seed fermentation effect on plant height was highly significant overall $(P<0.001)$ with the 0 week and 1 week treatments had higher values (though not different from each other) than the rest treatments at Week 5. This trend was also maintained with 0 week recording higher values than 1 week till Week 8, (Table 2)
Treatment effect on number of leaves is also highly significant $(P<0.001)$ with 0 week and 1 week not different from each other but different from the rest treatments at Week 5. At Week 6 onwards till the final assessment at Week 8, 0 week recorded significantly higher values than 1 week which in turn was higher than the rest treatments, (Table 3 ).

Treatment effect on leaf area was highly significant overall $(P<0.001)$. From Week 5 to the final assessment at Week 8,0 week recorded higher values than 1 week, which in turn is higher than the rest treatments, (Table 4).

Similarly, treatment effect on plant dry weight was highly significant $(P<0.001)$. 0 week recorded higher leaf dry weight than 1 week which in turn was higher than the rest treatments. Similar tread was recorded with stem dry weight, root dry weight and total dry weight, (Table 5)

Table 1: Effect of seed fermentation on germination percentage of Irvingia wombolu

\begin{tabular}{|c|c|c|c|c|c|c|c|}
\hline \multirow[b]{2}{*}{ Fermentation } & \multicolumn{7}{|c|}{ /weeks after sowing } \\
\hline & 2 & 3 & 4 & 5 & 6 & 7 & 8 \\
\hline 0 & 0.91 & 37.74 & 45.23 & 49.10 & 49.52 & 49.52 & 49.88 \\
\hline 1 & 0.91 & 24.27 & 34.36 & 40.73 & 41.09 & 41.09 & 41.47 \\
\hline 2 & 0.91 & 0.91 & 0.91 & 0.91 & 0.91 & 0.91 & 0.91 \\
\hline 3 & 0.91 & 0.91 & 0.91 & 0.91 & 0.91 & 0.91 & 0.91 \\
\hline 4 & 0.91 & 0.91 & 0.91 & 0.91 & 0.91 & 0.91 & 0.91 \\
\hline LSD .05 & ns & 5.02 & 5.78 & 4.94 & 4.75 & 4.75 & 4.80 \\
\hline
\end{tabular}

Table 2: Effect of seed fermentation on plant height of Irvingia wombolu

\begin{tabular}{|c|c|c|c|c|}
\hline \multirow[b]{2}{*}{ Fermentation } & \multicolumn{4}{|c|}{ /weeks after sowing } \\
\hline & 5 & 6 & 7 & 8 \\
\hline 0 & 1.26 & 1.37 & 1.40 & 1.40 \\
\hline 1 & 1.22 & 1.36 & 1.36 & 1.38 \\
\hline 2 & 0.00 & 0.00 & 0.00 & 0.00 \\
\hline 3 & 0.00 & 0.00 & 0.00 & 0.00 \\
\hline 4 & 0.00 & 0.00 & 0.00 & 0.00 \\
\hline LSD .05 & 0.11 & 0.13 & 0.13 & 0.13 \\
\hline
\end{tabular}

Table 3: Effect of seed fermentation on number of leaves of Irvingia wombolu

\begin{tabular}{|c|c|c|c|c|}
\hline \multirow[b]{2}{*}{ Fermentation } & \multicolumn{4}{|c|}{ /weeks after sowing } \\
\hline & 5 & 6 & 7 & 8 \\
\hline 0 & 1.82 & 2.15 & 2.31 & 2.41 \\
\hline 1 & 1.69 & 2.05 & 2.16 & 2.21 \\
\hline 2 & 0.91 & 0.91 & 0.91 & 0.91 \\
\hline 3 & .91 & 0.91 & 0.91 & 0.91 \\
\hline 4 & .91 & 0.91 & 0.91 & 0.91 \\
\hline LSD .05 & 0.15 & 0.08 & 0.09 & 0.07 \\
\hline
\end{tabular}


Am. J. Biotechnol. Mol. Sci., 2011, 1(2): 45-50

Table 4: Effect of seed fermentation on leaf area of Irvingia wombolu

\begin{tabular}{|c|c|c|c|c|}
\hline \multirow[b]{2}{*}{ Fermentation } & \multicolumn{4}{|c|}{ /weeks after sowing } \\
\hline & 5 & 6 & 7 & 8 \\
\hline 0 & 1.31 & 1.60 & 1.56 & 1.59 \\
\hline 1 & 1.07 & 1.49 & 1.49 & 1.50 \\
\hline 2 & 0.00 & 0.00 & 0.00 & 0.00 \\
\hline 3 & 0.00 & 0.00 & 0.00 & 0.00 \\
\hline 4 & 0.00 & 0.00 & 0.00 & 0.00 \\
\hline LSD .05 & 0.19 & 0.08 & 0.07 & 0.08 \\
\hline
\end{tabular}

Table 5: Effect of seed fermentation on dry weight of Irvingia wombolu

\begin{tabular}{llcll}
\hline Fermentation & LDWT & Dry weight $(\mathrm{g})$ & RDWT & TOTALDWT \\
\hline 0 & 0.46 & 0.43 & 0.20 & 0.71 \\
1 & 0.38 & 0.34 & 0.16 & 0.61 \\
2 & 0.00 & 0.00 & 0.00 & 0.00 \\
3 & 0.00 & 0.00 & 0.00 & 0.00 \\
4 & 0.00 & 0.00 & 0.00 & 0.00 \\
LSD .05 & 0.03 & 0.02 & 0.02 & 0.03 \\
\hline
\end{tabular}

\section{DISCUSSION}

The results obtained from this study indicate that Irvingia wombolu responded to seed fermentation treatments. In general, fermenting the seeds for 0 to 1 week was not detrimental to germination. However, the unfermented seeds exhibited a higher germination percentage compared to the 1 week fermented seeds. Thus it is speculated from the result obtained from this study that fermenting the seeds beyond 1 week had substantial impact on the viability of the seeds of the species. This result contrasted that findings of Mabundza et al. (2010) who obtained significant improved germination by fermenting the passion fruit seeds in 10\% sucrose solution for 14 days. They attributed the improved performance of seeds treated with sucrose to a supply of readily available carbohydrates for respiration during germination and development of seedling's roots as sucrose is a major form in which the products of carbohydrates catabolism are translocated into developing seedlings. Although extraction by fermentation is recommended for some seeds such as tomatoes, over fermentation may lead to sprouting of the seeds or reduce viability (Liptay, 1989).

The lack of germination in the seeds fermented beyond 1 week may be a consequence of seed death, which may be due to imbibition, oxygen starvation and elevated temperature during fermentation. This agrees with Hartmann et al. (2007) who pointed out that excessive fermentation reduces seed viability. Kramer (1983) attributed the harmful effect of extended pre-soaking to restriction of oxygen supply during some critical metabolic stage of germination. The $50 \%$ germination recorded in the unfermented seeds which were stored dry for 4 weeks before sowing, when compared with the result obtained by Nya et al. (2006), suggests that $I$. wombolu seeds are recalcitrant and are best sown immediately the fruits are harvested or picked from the forest floor.

Fermentation also negatively influenced other growth parameters measured such as plant height, mean number of leaves, leaf area and dry matter accumulation, with the unfermented seeds performing better. This is not surprising as the above stated parameters are indicative of meristermatic activities and subsequent growth over time. Since the unfermented seeds were not subjected to oxygen starvation and other physiological stress during fermentation, they exhibited higher germination percentage and subsequent higher seedling vigour when compared to the fermented seeds.

\section{CONCLUSION}

The results revealed a deleterious effect of fermentation on the germination of the species, thus 
fermenting the seeds of $I$. wombolu beyond one week could impede viability. This study has further confirmed that $I$. wombolu seeds are best sown immediately the fruits are harvested or picked from the forest floor.

\section{REFERENCES}

Abirami, K., J. Rema, P.A. Mathew, V. Srinivasan and S. Hamza, 2010. Effect of different propagation media on seed germination,seedling growth and vigour of nutmeg (Myristica fragrans Houtt). Journal of Medicinal Plants Research 4(19): 2054-2058.

Aduradola, A.M., Adeola, B.F. and Adedire, M.O. 2005. Enhancing germination in seeds of African star apple, Chrysophyllum albidum (G. Don). Journal of Food, Agriculture \& Environment 3(2): 285-287.

Ainge, L. and Brown, N. 2001. Irvingia gabonensis and Irvingia wombolu. A State of the Knowledge Report. CARPE.

http://carpe.umd.edu/resources/Dorcuments/reportaingebrown2001pdf/wiew.20K

Asaba Meteorological Centre 2003. National meteorological report. Meteorological Bulletin. Lagos, Nigeria.

Atangana. A. R., Ukafor V., Anegbeh, P., Asaah, E., Tchoundjeu. Z,, Fondoun, J. M., Ndoumbe $M$ and Leakey, R.R.B. 2002. Domestication of Irvingia gabonensis: 2. The selection of multiple traits for potential cultivars from Cameroon and Nigeria. Agroforestry Systems 55: 221-229.

Awodoyin, R.O., Ogunyemi, S. and Ladipo, D.O. 2001. Studies on some nursery management techniques for Irvingia wombulu (syn. Exelsa) ex. Okafor. Nigerian Journal of Ecology 3: 24-28.

Ayuk, E.T., Duguma, B., Franzel, S., Kengue, J., Mollet, S.M., Tiki-Manga, T. and Zenkekeng, P., 1999. Uses, management and economic potentials Irvingia gabonensis in the humid lowlands of Cameroon. Forest Ecology and Management, 113: 1-9.

Bowes, B.G., 1999. A Colour atlas of plant propagation and conservation. Manson Publishing Ltd, London.

Desai, B.B., P.M. Kotecha and D.K. Salunkhe, 1997. Seeds handbook. Biology, production, processing and storage. Marcel Dekker, N.Y.

Ejiofor, M. A. N. 1994. Nutritional values of Ogbono (Irvingia gabonensis var. excelsa). Paper presented at the ICRAF-IITA Conference on Irvingia gabonensis, Ibadan, Nigeria, $20^{\text {th }}$ May.

Fajimi, O., Sarumi, M.B., Olayode, M.N., Gamra, E.O. and Sanusi, S.I. 2007. In-vitro propagation of Irvingia gabonensis. African Journal of Biotechnology 6(8): 976-978.
Genstat 2007. Genstat discovery edition 3. Lawes Agricultural Research Trust, Rothamsted Experimental Station.

Gomez, K.A. and Gomez, A.A. 1984. Statistical procedures for agricultural research $2^{\text {nd }}$ edition. John Wiley and Sons, N.Y. 680pp.

Harris, D. J. 1996. A revision of the Irvvingiaceae in Africa. Bull . Jard . Bot . Belg . 65: 143-196.

Hartmann H . T ., Kester, D . E. Davies, F. T., and Genve, R. I., 2007. Hartmann and Kester's plant propagation, principles and practices. Seventh edition. Prentice-Hall of India Private limited pp880.

Hossain, M.A, Arefin, M.K, Khan, B.M. and Rahman, M.A. 2005. Effects of seed treatments on germination and seedling growth attributes of horitaki (Terminalia chebula Retz.) in the nursery. Research Journal of Agriculture and Biological Sciences 1(2): 135-141.

Joseph, K. \& Aworh, O. C. 1991. Composition, sensory quality and respiration during ripening and storage of edible wild mango (Irvingia gabonensis). International Journal of Food Science \& Technology 26: 3 pp.337342.

Joseph, K. \& Aworh, O. C. 1992. Post-harvest treatment of wild mango (Irvingia gabonensis) for improved shelf life. Food Chemistry 44: 1 pp.45-48.

Kramer, P.J., 1983. Water Relations of Plants. Academic press limited, London

Ladipo, D.O., 2000. Harvesting of Irvingia gabonensis and Irvingia wombulu in Nigerian forests; potentials for the development of sustainable systems. Paper presented at the Seminar Harvesting of Non-Wood Forest Products, held at Menemen-Izmir, Turkey on 2-8 October 2000. http://www.fao.org/ documents/show_cdr.asp?url_file=/ DOCREP/005/Y44496E/ Y4496̄E32.htm.

Ladipo, D.O., Fondoun, J.M and Gana, N., 1996. Domestication of the bush mango (Irvingia spp) : Some exploitable intra-specific variation in West and Central Africa. In: Domestication and Commercialization of Non-Timber Forest Products for Agroforestry (eds.) Leakey, R.R.B., Temu, A.B., Melnyk, M. and Vantomme, P. Non-Timber Forest Products Paper 9, FAO Rome. Pp 193-206.

Leakey, R.R.B. 1999. Farmers top priority fruit trees. Agroforestry Today. 11(3-4): 11-15

Liptay, A. 1989. Extraction procedures for optimal tomatoes seed quality. Acta Hort. 253: 163-165

Lowe, A.J.A., Gillies, C.M., Wilson. J. and Dawson, I.K. 2000. Conservation genetics of bush mango from central/west Africa: Implications from random amplified polymorphic DNA analysis. Molecular Ecology 9: 831841. 
Mabundza, R.M., P.K. Wahome and M.T. Masarirambi, 2010. Effects of different pre-germination

treatment methods on the germination of passion (Passiflora edulis) seeds. J. Agric. Soc. Sci., 6: 57-60

MacDonald, B., 1986. Practical woody plant propagation for nursery growers vol. 1. Timber Press, Portland Oregon.

Moss, R.1995. Unexploited tree crops: components of productive and more sustainable farming systems. Journal for Farming Systems Research Extension 5(1): 107-117.

Nya P. J., Omokaro D. N. and Nkang A. E. (2000). Comparative studies of seed morphology, moisture content and seed germination of two varieties of Irvingia gabonensis. Global J. Pure \& Appl. Sci. 6(3): 375-378.

Nya, P.I., Omokaro, D.N. and Nkang, A.E. 2006. Effect of pretreatments on seed viability during fruit development of two varieties of Irvingia gabonensis. Global Journal of Pure and Applied Sciences 12(2): 141-148.

Okafor, J.C. 1975. Varietal delimination in Irvingia gabonensis (Irvingiaceae). Bulletin du Jardin Botanique Nationale de Belgique 45(1-2): 211-221.

Onyekwelu JC, Fayose OJ. 2007. Effect of storage methods on the germination and proximate composition of Treculia africana seeds. Conference on International Agricultural Research for Development. University of Kassel-Witzenhausen and University of Göttingen, October 9-11, 2007.

Schopmeyer, C.S., 1974. Woody plants in The United States. US Department of Agriculture Handbook 410. Washinton DC. US Govt. Printing Office.
Schreckenberg, K., Leakey, R.R.B and Z. Tchoundjeu 2001 opportunities and constraints faced by resource - poor farmers in investing in the planting and improvement of indigeneous trees for income generation. European Tropical Forest Research Network Newsletter No 32. www.Etfrn/newsletter/nl32-01p6.html.

Sharma RK, Sharma S, Sharma SS., 2006. Seed germination behaviour of some medicinal plants of Lahaul and Spiti cold desert (Himachal Pradesh): implications for conservation and cultivation. Curr Sci 90:1113-8

Siddique, A.B. and Wright D., 2003: Effects of different seed drying methods on moisture Percentage and Seed Quality (Viability and Vigour) of Pea Seeds (Pisum sativum L.) Pakistan Journal of Agronomy 2 (4): 201-208

Steiner, J.J. and B.F. Letizia, 1989. A seed cleaning sluice for fleshy-fruited vegetables from small plots. HortScience 21 : 1066-1067

Tchoundjeu, Z., Duguma, B., Marie-Laure, T. and MarieLaure, N. 1997. The domestication of indegenious agroforestry trees of West and Central Africa. CARPE: Limbe Non-Wood Forest Products Workshop. Web address: http:// carpe.gecp.virginia.edu/products/products2a.asp

Tchoundjeu, Z., Kengue, J. and R.R.B. Leakey 2002. Domestication 71 of Darcryodes edulis: state-of-theart. Forests, Trees and Livelihoods 12: 3-13.

Willan, R.L. 1985. A guide to forest seed handling, with special reference to the tropics FAO Forestry Paper $20 / 2$.

http://www.fao.org/docrep/006/ad232e/AD232E00.htm \#TOC 